Article

\title{
Improved Recrystallization Resistance of Al-Cu-Li-Zr Alloy through Ce Addition
}

\author{
Xinxiang Yu ${ }^{1,2, *} \mathbb{B}$, Han Dai ${ }^{1,2}$, Zhutie $\mathrm{Li}^{2}$, Jie Sun ${ }^{1}$, Junfeng Zhao ${ }^{1}$, Caiqiong $\mathrm{Li}^{1}$ and \\ Wenwen Liu ${ }^{1}$ \\ 1 Laboratory of Advanced Light Alloy Materials and Devices, Yantai Nanshan University, \\ Longkou 265713, China; daihan1985@189.cn (H.D.); sunjie19860304@163.com (J.S.); \\ zhaojunfengcc@163.com (J.Z.); licaiqiong666@163.com (C.L.); liuwenwen2@163.com (W.L.) \\ 2 Testing Center, Hang Xin Material Technology Co. Ltd., Longkou 264006, China; lizhutie@nanshan.com.cn \\ * Correspondence: yuxinxiangcn@163.com; Tel.: +86-0535-859-0938
}

Received: 5 November 2018; Accepted: 5 December 2018; Published: 7 December 2018

\begin{abstract}
The effects of the addition of $0.29 \mathrm{wt} \% \mathrm{Ce}$ on the recrystallization behavior of an $\mathrm{Al}-\mathrm{Cu}-\mathrm{Li}-0.13 \mathrm{Zr}$ (wt \%) alloy during isothermal annealing were investigated. Ce addition greatly improved inhibition of recrystallization in this alloy compared with that in the Ce-free alloy. The texture of the Ce-containing alloy contained a large amount of $\beta$-fibers and fibrous unrecrystallized grain microstructures distributed along the rolling direction in the overall annealing process. The improved recrystallization resistance endowed by Ce addition can be attributed to the large number of small $\mathrm{Al}_{8} \mathrm{Cu}_{4} \mathrm{Ce}$ species formed on the grain boundary. These fine particles with high-temperature stability can exert a Zener pressure on the $\mathrm{Al}_{3} \mathrm{Zr}$ dispersoid-free grain boundary. The yield strength of the Ce-containing alloy increased significantly, to $38 \mathrm{MPa}$, and the fracture toughness improved by $56.28 \%$ compared with those of the Ce-free alloy. This work provides a convenient and economical method for enhancing the overall performance of an $\mathrm{Al}-\mathrm{Cu}-\mathrm{Li}-\mathrm{Zr}$ alloy via recrystallization inhibition by $\mathrm{Ce}$ addition.
\end{abstract}

Keywords: $\mathrm{Al}-\mathrm{Cu}-\mathrm{Li}$ alloy; cerium; texture; inhibition of recrystallization; microstructure

\section{Introduction}

$\mathrm{Al}-\mathrm{Cu}-\mathrm{Li}$-based alloys are of great interest as aerospace structural materials, which require a combination of high strength, low density, high fracture toughness, and good corrosion resistance [1]. Inhibition of alloy recrystallization has been extensively used to improve the overall performances of these $\mathrm{Al}$ alloys. An increase in the number of small grains and distribution of fiber-like unrecrystallized microstructures via recrystallization inhibition greatly improves the strength and fracture toughness of an $\mathrm{Al}$ alloy [2-5]. In the fabrication of high-performance $\mathrm{Al}-\mathrm{Cu}-\mathrm{Li}$ alloys, in particular, recrystallization inhibition can be used to avoid intergranular fractures caused by lower Li segregation levels in small-angle grain boundaries of unrecrystallized grains, and improve the alloy strength and fracture toughness [6,7]. This greatly extends the scope of their applications.

Well-distributed nano-sized dispersoids can effectively retain their deformed structure through pinning dislocation and sub-boundaries to inhibit recrystallization and grain growth [8]. Many attempts have been made to inhibit recrystallization in $\mathrm{Al}$ alloys through precipitating $\mathrm{L}_{2}$-structured nano-sized dispersoids of $\mathrm{Al}_{3} \mathrm{Zr}$ [9,10]. However, addition of $\mathrm{Zr}$ alone often gives a highly inhomogeneous distribution of dispersoids [11]. Recently, joint addition of $\mathrm{Zr}$ and rare earth elements (e.g., ScZr and ErZr) has been used to solve this problem [12], but this makes homogenization annealing processes complicated. 
Normally the low solute supersaturation near dendrite boundaries results in the dispersoid-free zones formed in $\mathrm{Zr}$ containing alloy, leading to dispersoid banding in rolled plates and a low pinning pressure in the critical region of grain boundaries where recrystallization easily initiates [11]. Similar to the opposite micro segregation patterns of $\mathrm{Mn}$ and $\mathrm{Zr}$ in $\mathrm{Al}$, the joint addition of $\mathrm{Ce}$ and $\mathrm{Zr}$ is thought to produce more uniform dispersion coverage [13]. The precipitation of Ce-containing phase along dendrite boundaries easily occur and it is hardly dissolved in solid solution, due to its micro segregation patterns [14,15], and the poor solid solubility of Ce in Al alloy (only $0.05 \mathrm{wt} \%$ at $650{ }^{\circ} \mathrm{C}$ ) [16]. These fine Ce-containing phases that contribute towards Zener pinning would have a potent effect in retarding grain boundary migration [17], especially on an $\mathrm{Al}_{3} \mathrm{Zr}$ dispersoid-free grain boundary. Moreover, $\mathrm{Ce}$ with medium-price and it seems an effective texture modifier in alloy [18]. However, the rare earth element $\mathrm{Ce}$ has traditionally been used as a micro-alloying element in $\mathrm{Al}$ alloys to purify melts [19] and refine dendritic structures [20,21]. Improved recrystallization resistance was only clearly observed during annealing of the $\mathrm{Mg}-\mathrm{Zn}-\mathrm{Zr}-\mathrm{Ce}$ alloy because of the Zener pinning effect of the Ce enrichment phase [17]. Similar recrystallization inhibition has also been observed in $\mathrm{Al}$ alloys [22], therefore, we investigated the effects of $\mathrm{Ce}$ addition on recrystallization inhibition in an $\mathrm{Al}-\mathrm{Cu}-\mathrm{Li}-\mathrm{Zr}$ alloy.

In this study, the effects of Ce addition on inhibition of recrystallization in an $\mathrm{Al}-\mathrm{Cu}-\mathrm{Li}-\mathrm{Zr}$ alloy were investigated during isothermal annealing after high-strain rolling. Ce addition to an $\mathrm{Al}-\mathrm{Cu}-\mathrm{Li}-\mathrm{Zr}$ alloy greatly improved its recrystallization resistance during isothermal annealing. The observed evolution of textures and microstructures, and the mechanical properties confirmed that Ce addition inhibited recrystallization. Ce addition considerably improves the strength and fracture toughness of $\mathrm{Al}-\mathrm{Cu}-\mathrm{Li}-\mathrm{Zr}$ alloys, and this provides a convenient and economical method for enhancement of their overall performance.

\section{Materials and Methods}

The composition of the experimental alloy is presented in Table 1. Master alloys of $\mathrm{Al}-\mathrm{Cu}, \mathrm{Al}-\mathrm{Zr}$, $\mathrm{Al}-\mathrm{Ce}$, and pure $\mathrm{Ag}, \mathrm{Mg}$, $\mathrm{Li}$, and the remainder $\mathrm{Al}$ were melted in a vacuum induction melting furnace in a controlled Ar gas atmosphere, in a high-purity graphite crucible. Casting was performed under Ar, using a $\mathrm{Cu}$ mold surrounded with cooling water [23]. The as-cast ingots were homogenized in two stages, at $470{ }^{\circ} \mathrm{C} / 8 \mathrm{~h}$ and $510^{\circ} \mathrm{C} / 16 \mathrm{~h}$ in a salt bath, followed by air cooling to room temperature. The ingots were converted into plates of thickness $4.5 \mathrm{~mm}$ by hot rolling at $400-450{ }^{\circ} \mathrm{C}$, under a total rolling strain of $80.43 \%$. The hot-rolled plates were held at $450{ }^{\circ} \mathrm{C}$ for $2 \mathrm{~h}$ and then cooled to room temperature in the furnace. Finally, these plates were cold rolled by $55.55 \%$ to a thickness of approximately $2.0 \mathrm{~mm}$. The cold-rolled plates were annealed in a salt-bath furnace under various isothermal conditions, i.e., $380{ }^{\circ} \mathrm{C} / 0.5 \mathrm{~h}, 430^{\circ} \mathrm{C} / 0.5 \mathrm{~h}, 450{ }^{\circ} \mathrm{C} / 1 \mathrm{~h}, 520^{\circ} \mathrm{C} / 0.5 \mathrm{~h}, 520^{\circ} \mathrm{C} / 1 \mathrm{~h}$, and $520^{\circ} \mathrm{C} / 4 \mathrm{~h}$. Samples for tensile and fracture toughness tests were prepared by solution treatment at $520^{\circ} \mathrm{C}$ for $1 \mathrm{~h}$, water quenching, and artificial aging at $180{ }^{\circ} \mathrm{C}$ for $22 \mathrm{~h}$. Tensile tests were performed at a loading speed of $2 \mathrm{~mm} / \mathrm{min}$ with an Instron3369 machine (INSTRON, Boston, MA, USA). The fracture toughness (tear resistance) was determined by the Kahn tear test; the relevant parameter was the unit initiation energy (UIE), i.e., the energy dissipated before crack propagation [24]. The grain structure was observed by optical microscopy under polarized light. The macro-textures and phases of the alloys were investigated by X-ray diffraction (XRD; Rigaku D/max-2400, Ultima IV, Rigaku Corp., Tokyo, Japan). Automated electron backscatter diffraction (EBSD) was performed with a FEI-Nova Nano SEM 450 scanning electron microscope (FEI Company, Hillsboro, OR, USA) equipped with a field-emission gun and a HKL-NordlysII EBSD detector (Oxford Instruments, Oxford, UK). The gathered data were analyzed using TSL OIM Analysis 7 software (EDAX Inc., Mahwah, NJ, USA).

Table 1. Chemical composition of investigated alloys (wt \%).

\begin{tabular}{ccccccc}
\hline Alloys & $\mathbf{L i}$ & $\mathbf{C u}$ & $\mathbf{A g}$ & $\mathbf{M g}$ & $\mathbf{Z r}$ & $\mathbf{C e}$ \\
\hline Ce-free alloy & 1.29 & 4.62 & 0.41 & 0.39 & 0.14 & - \\
Ce-containing alloy & 1.31 & 4.63 & 0.38 & 0.40 & 0.13 & 0.29 \\
\hline
\end{tabular}




\section{Results and Discussion}

Figure 1 shows the recrystallization degree of the $\mathrm{Al}-\mathrm{Cu}-\mathrm{Li}-0.13 \mathrm{Zr}-0.29 \mathrm{Ce}$ alloy (Ce-containing alloy). The degree is far lower than that for the $\mathrm{Al}-\mathrm{Cu}-\mathrm{Li}-0.14 \mathrm{Zr}$ alloy (Ce-free alloy) under the same conditions, for all annealing processes. As shown in Figure 1a, little recrystallization of the Ce-containing alloy can be observed along the rolling direction for annealing at temperatures below $520{ }^{\circ} \mathrm{C}$. Clear recrystallization only occurs near the sample surface zone after annealing at $520{ }^{\circ} \mathrm{C}$ for $1 \mathrm{~h}$. There are still large areas of unrecrystallized grain structures in the middle area of the sample, even for annealing times of up to $4 \mathrm{~h}$ (Figure 1a) In contrast to the case for the Ce-containing alloy, unrecrystallized microstructures in the Ce-free alloy can only be observed for annealing at $380^{\circ} \mathrm{C}$ for $0.5 \mathrm{~h}$. Significant recrystallization occurs after annealing at $430^{\circ} \mathrm{C}$ for $0.5 \mathrm{~h}$, and further recrystallization occurs after annealing at $450{ }^{\circ} \mathrm{C}$ for $1 \mathrm{~h}$. Almost complete recrystallization can be observed after annealing at $520^{\circ} \mathrm{C}$ for $1 \mathrm{~h}$, as shown in Figure $1 \mathrm{~b}$. Ce addition effectively improves the recrystallization resistance of $\mathrm{Al}-\mathrm{Cu}-\mathrm{Li}-\mathrm{Zr}$ alloys.

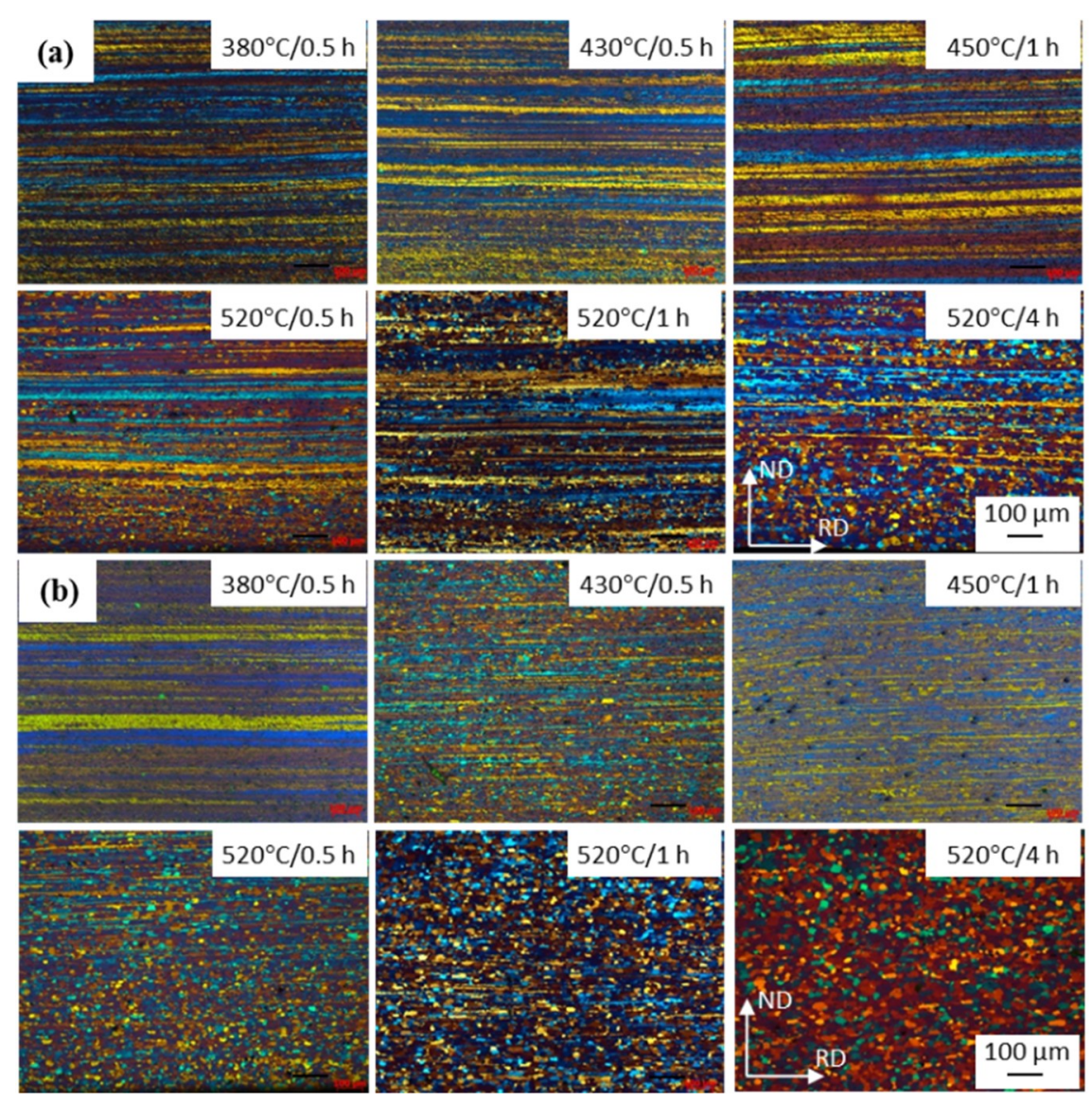

Figure 1. Optical microstructures for the alloys under different annealing temperatures and time: (a) Ce-containing alloy; (b) Ce-free alloy.

The evolutions of the macro-textures (grain orientations) of the Ce-containing and Ce-free alloys were compared to clarify the process of recrystallization inhibition in $\mathrm{Al}-\mathrm{Cu}-\mathrm{Li}-\mathrm{Zr}$ by $\mathrm{Ce}$ addition under various isothermal annealing conditions (Figures 2 and 3). Figure 2a shows that typical deformation microstructures such as $\beta$-fibers, and textures with the $\mathrm{Cu}$ orientation $\{112\}<111>$, $S$ orientation $\{123\}<634>$, and brass orientation $\{011\}<211>$, were clearly formed in the Ce-containing alloy by high-strain rolling. Figures 2 and 3 show that in the Ce-containing alloy, the $\beta$-fiber texture was first partly replaced by the Cubic texture $\{001\}<100>$ at $520^{\circ} \mathrm{C}$, which is higher than that in the case of the Ce-free alloy, i.e., about $430{ }^{\circ} \mathrm{C}$. The unrecrystallized $\beta$-fiber rolling texture was always retained 
during isothermal annealing, as shown in Figure $2 \mathrm{~b}-\mathrm{e}$. This indicates that Ce addition improved inhibition of recrystallization.

(a)

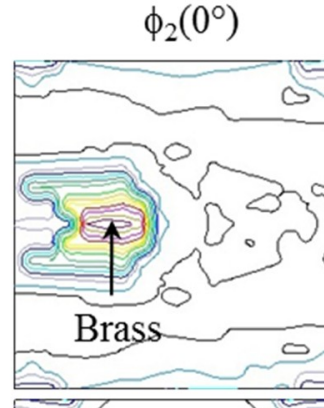

(b)
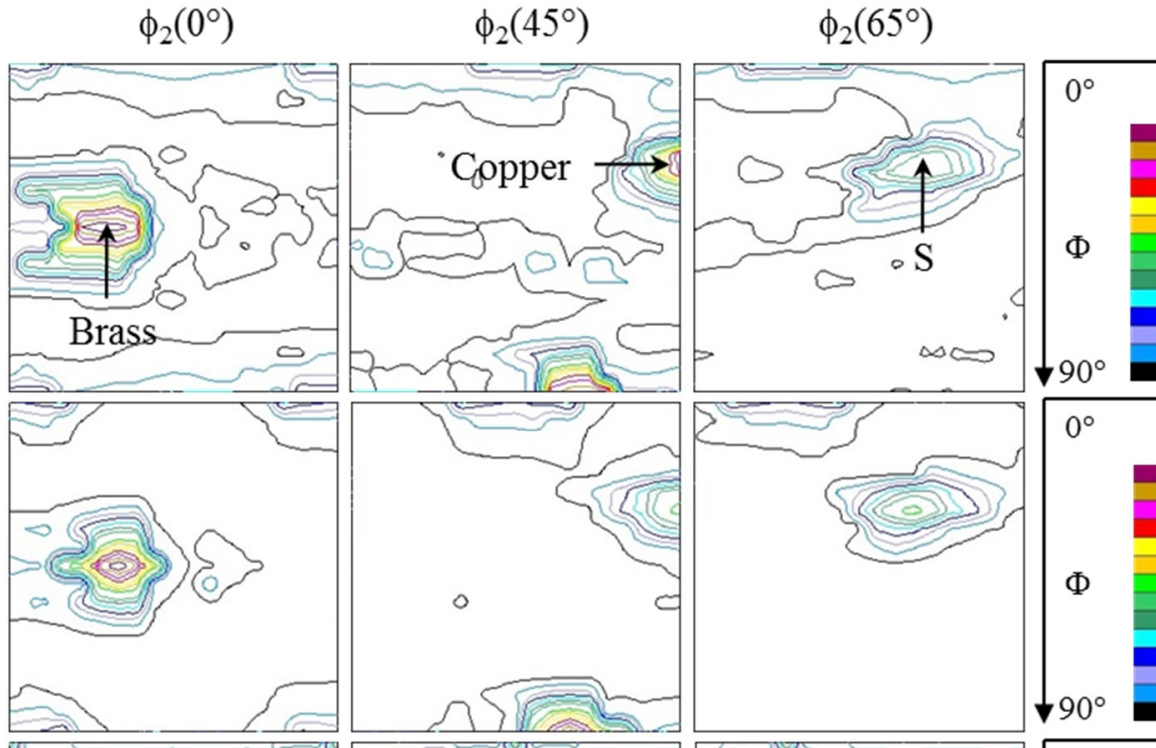

(c)
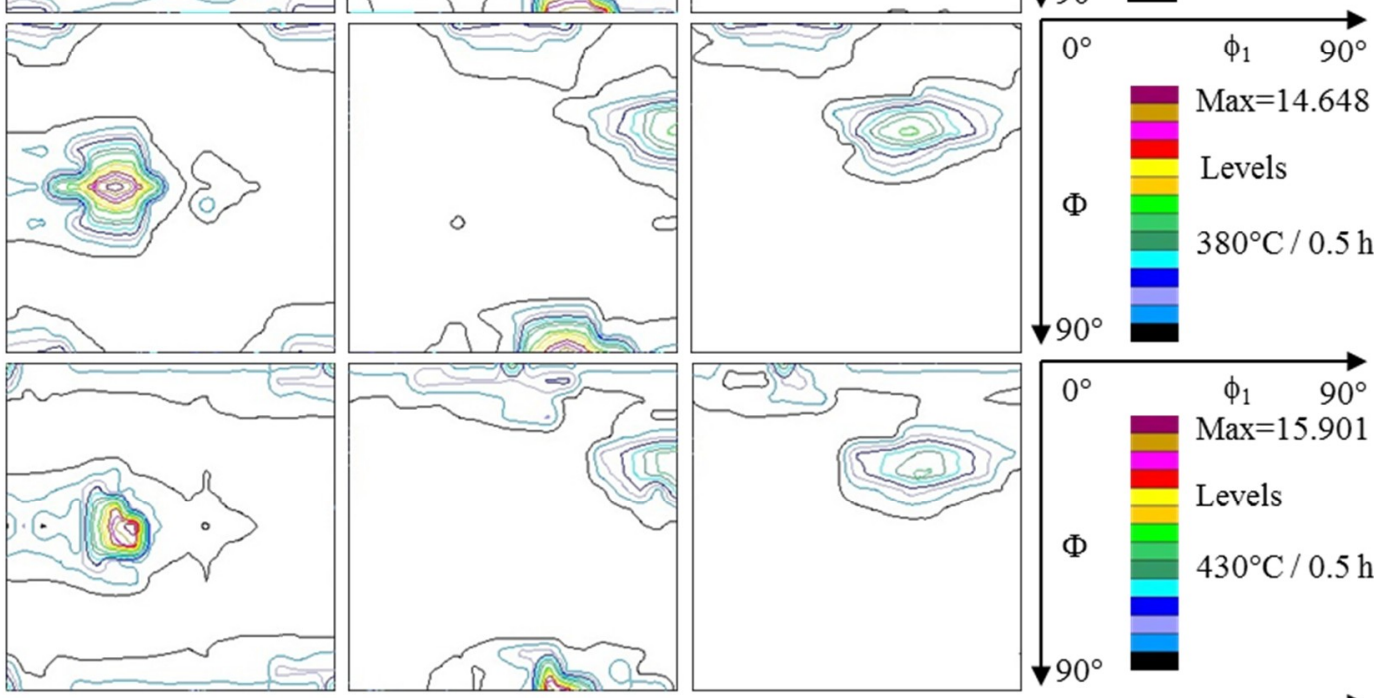

(d)
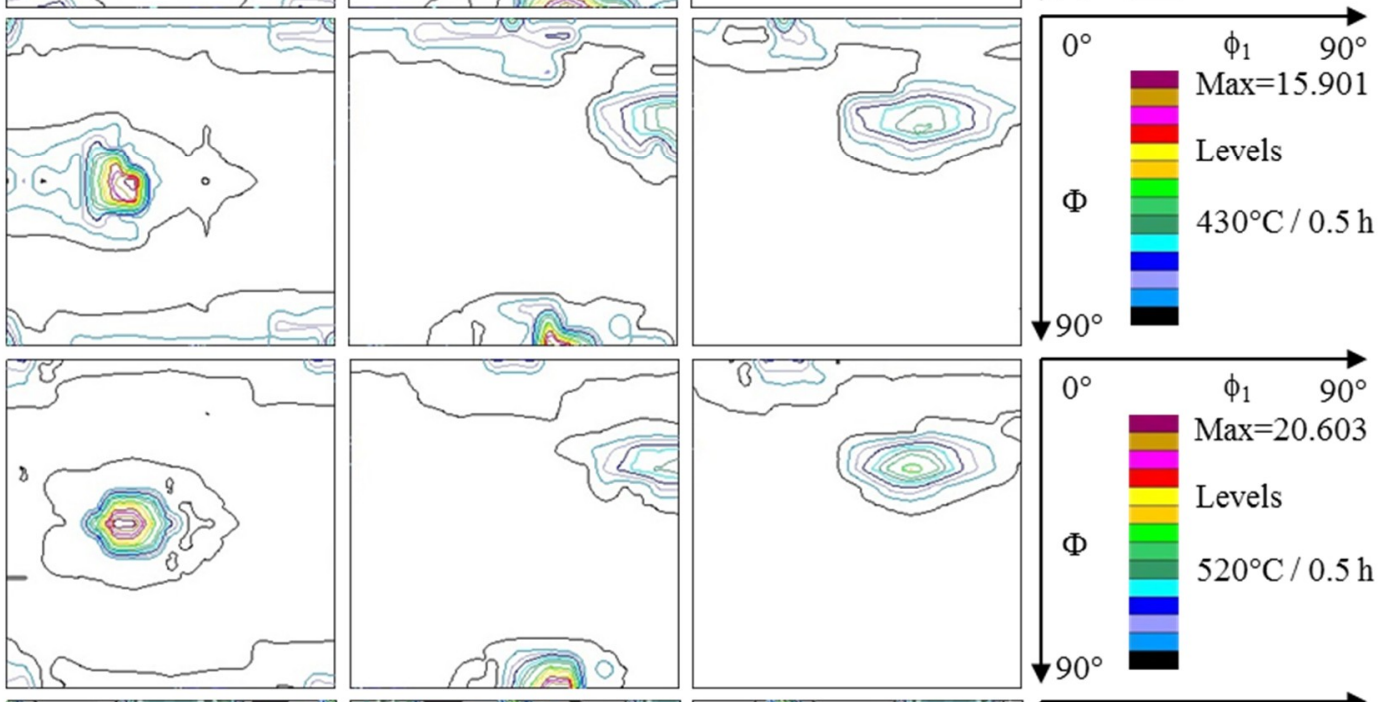

(e)
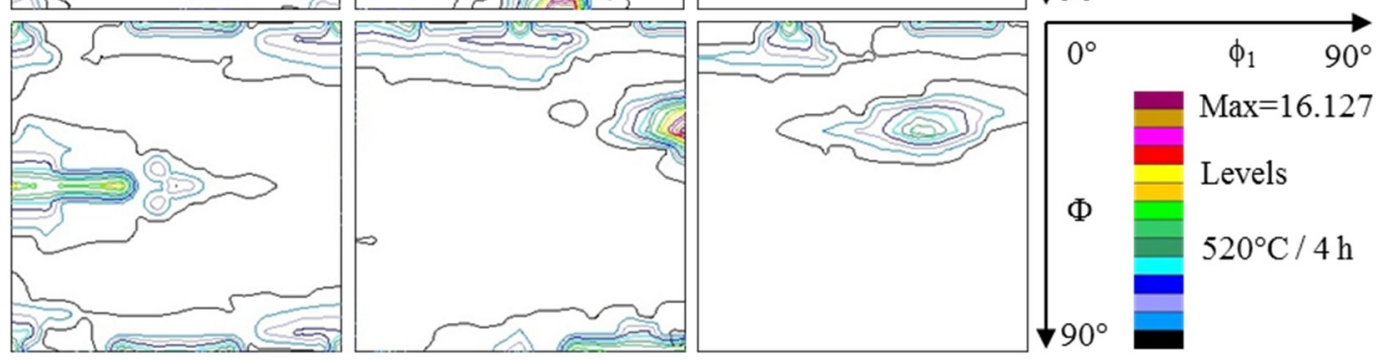

Figure 2. Orientation distribution function (ODFs) representative sections of cold rolled Ce-containing alloy under different annealing temperatures and times: (a) cold rolled; (b) $380^{\circ} \mathrm{C} / 0.5 \mathrm{~h} ;$ (c) $430^{\circ} \mathrm{C} / 0.5 \mathrm{~h}$; (d) $520{ }^{\circ} \mathrm{C} / 0.5 \mathrm{~h} ;(\mathbf{e}) 520{ }^{\circ} \mathrm{C} / 4 \mathrm{~h}$. 
(b)

(a)

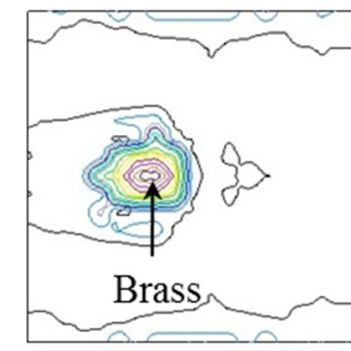

$\phi_{2}\left(0^{\circ}\right)$

$\phi_{2}\left(45^{\circ}\right)$

$\phi_{2}\left(65^{\circ}\right)$

(a)
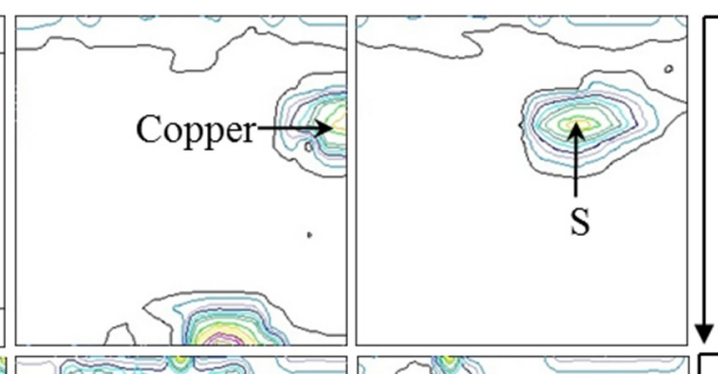

$\sqrt{0^{\circ}}$

$\phi_{1} \quad 90^{\circ}$

$\operatorname{Max}=15.150$

Levels

Cold rolled

$\sqrt{ } 90^{\circ}$
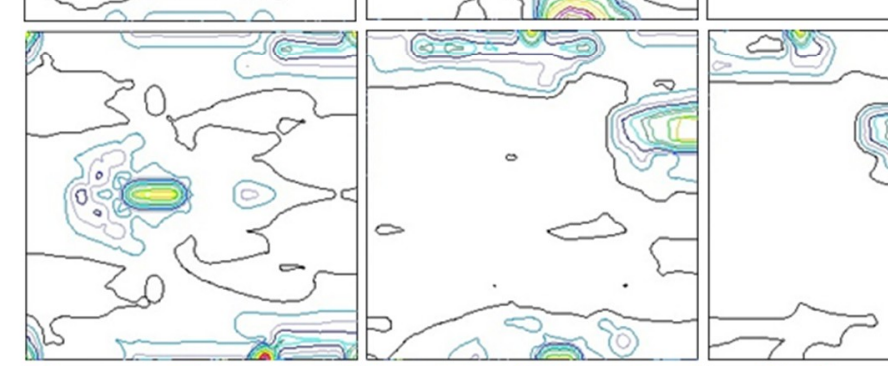

(c)
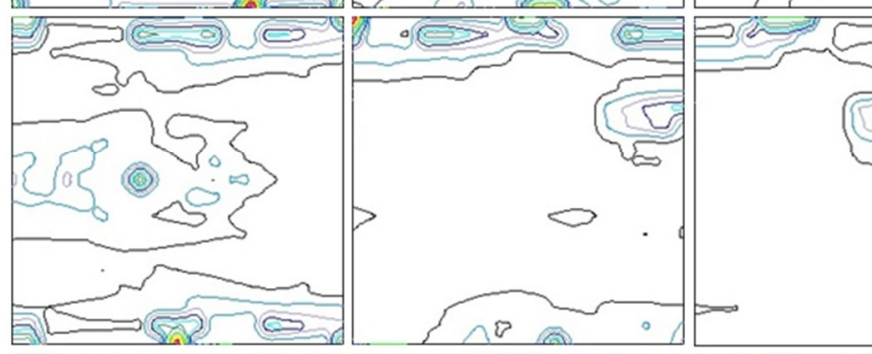

(d)
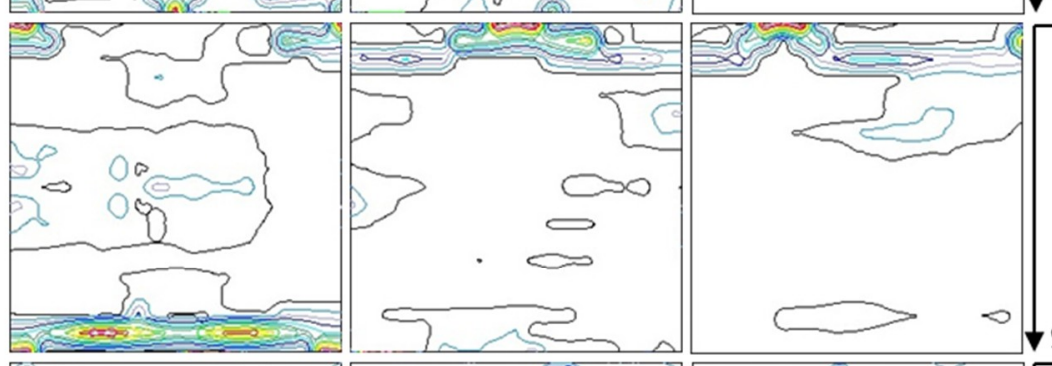

$0^{\circ}$

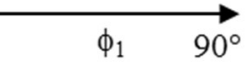

$0^{\circ}$

$\phi_{1} \quad 90^{\circ}$
$\operatorname{Max}=15.927$

$90=2$

(e)
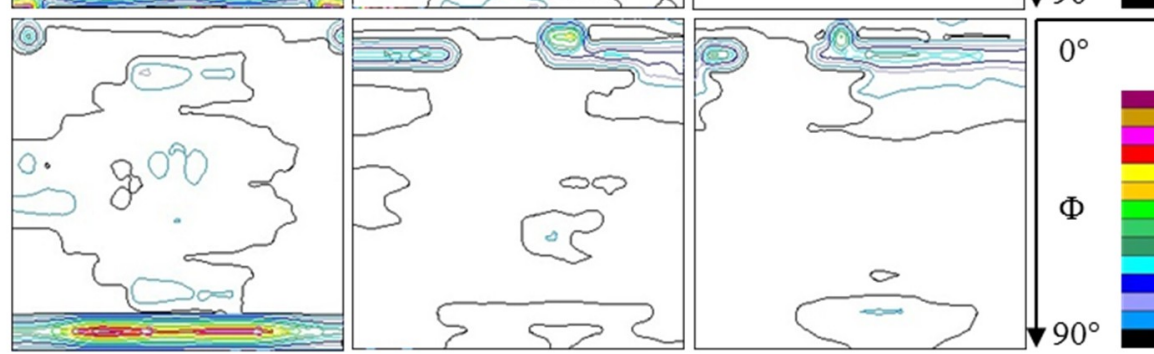

Levels

$430^{\circ} \mathrm{C} / 0.5 \mathrm{~h}$

政

$\operatorname{Max}=18.812$

Levels

$520^{\circ} \mathrm{C} / 0.5 \mathrm{~h}$

$\phi_{1} \quad 90^{\circ}$

$\operatorname{Max}=15.143$

Levels

$520^{\circ} \mathrm{C} / 4 \mathrm{~h}$

Figure 3. ODFs representative sections of cold rolled Ce-free alloy under different annealing temperatures and time: (a) cold rolled; (b) $380{ }^{\circ} \mathrm{C} / 0.5 \mathrm{~h}$; (c) $430{ }^{\circ} \mathrm{C} / 0.5 \mathrm{~h}$; (d) $520{ }^{\circ} \mathrm{C} / 0.5 \mathrm{~h}$; (e) $520^{\circ} \mathrm{C} / 4 \mathrm{~h}$.

Quantitative date for the unrecrystallized $\beta$-fiber and $\alpha$-fiber textures are presented in Figure 4; the data show the maximum intensities of the orientation distribution function (ODF) $f(\mathrm{~g})$. Figure 4 shows that the $f(\mathrm{~g})$ value for the as-rolled Ce-containing alloy was lower than that for the Ce-free alloy. It can be assumed that particle-stimulated nucleation (PSN) of recrystallization occurred [25] and more randomly oriented nuclei formed [26] during hot deformation because of the formation of coarse Ce enrichment particles in the Ce-containing alloy [14]. The SEM images and XRD patterns of the as-homogenized material clearly show the presence of a large number of coarse $\mathrm{Al}_{8} \mathrm{Cu}_{4} \mathrm{Ce}$ particles in Ce-containing alloy, and only a few $\mathrm{AlCu}_{2} \mathrm{Zr}$ particles in Ce-free alloy (Figure 5). Obviously, the number density of coarse particles in the Ce-containing alloy is larger than that in Ce-free alloy. 
Because of more coarse particles in the Ce-containing alloy, particle-stimulated nucleation (PSN) of recrystallization occurs and more randomly oriented nuclei are formed during hot deformation. This analysis is confirmed by the texture of the alloys after the hot rolling stage in Figure 6 . The lower stored energy after deformation through PSN recrystallization in the Ce-containing alloy, therefore, decreased the recrystallization driving force of this alloy [27]. In addition, unlike the gradual decreases in the $\alpha$ - and $\beta$-orientation lines of the Ce-free alloy, the intensities of the $\beta$-fiber texture at the positions of brass and $\mathrm{S}$ orientations in the Ce-containing alloy continuously increased with increasing annealing temperature up to an annealing time of $4 \mathrm{~h}$ at $520^{\circ} \mathrm{C}$. After annealing for $4 \mathrm{~h}$, the orientation densities of brass and $S$ dropped, whereas the $C u\{112\}<111>$ and Goss $\{011\}<100>$ textures increased, as shown in Figure $4 \mathrm{a}$,c. In general, the $f(\mathrm{~g})$ values for both $\alpha$-fibers and $\beta$-fibers in the Ce-containing alloy (Figure $4 \mathrm{a}, \mathrm{c}$ ) were much higher than those for the Ce-free alloy (Figure $4 \mathrm{~b}$,d) when the annealing temperature reached $520^{\circ} \mathrm{C}$. The initial increase and subsequent decrease in the value of $f(\mathrm{~g}) \mathrm{can}$ be explained as follows. Because of the strong inhibition of recrystallization achieved by Ce addition during isothermal annealing after high-strain rolling (Figure 1), recovery only occurs via formation of a large number of subgrains with the $\beta$ rolling orientation. The intensities of the preferred nucleation $\mathrm{S}$ and brass orientations increase significantly with annealing temperature [28]. When annealing is extended to $4 \mathrm{~h}$, recovery is associated with the accumulation of misorientations or annihilation of dislocations, leading to the formation of movable high-angle sub-boundaries. The 'overcritial' sub-grains (given by the Gibbs Thomson effect) grow and become growing recrystallization grain [22], with a corresponding decrease in the $f(\mathrm{~g})$ value. Because of the roles played by Ce enrichment particles at different stages, improved recrystallization resistance of the Ce-containing alloy is achieved during isothermal annealing.
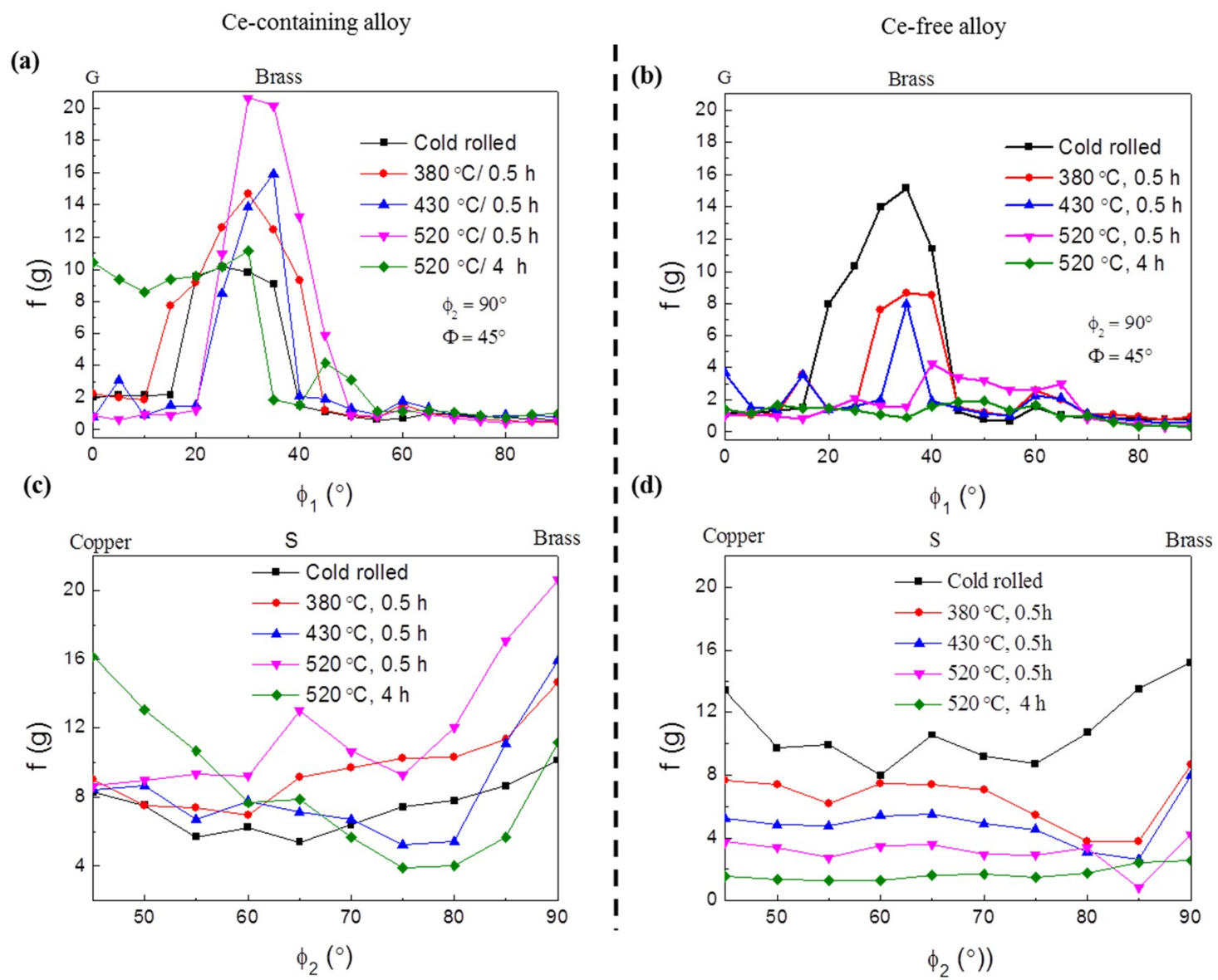

Figure 4. Texture evolution of the experimental alloys annealed under different annealing temperatures and time: (a,b) $\alpha$-fiber; (c,d) $\beta$-fiber. 

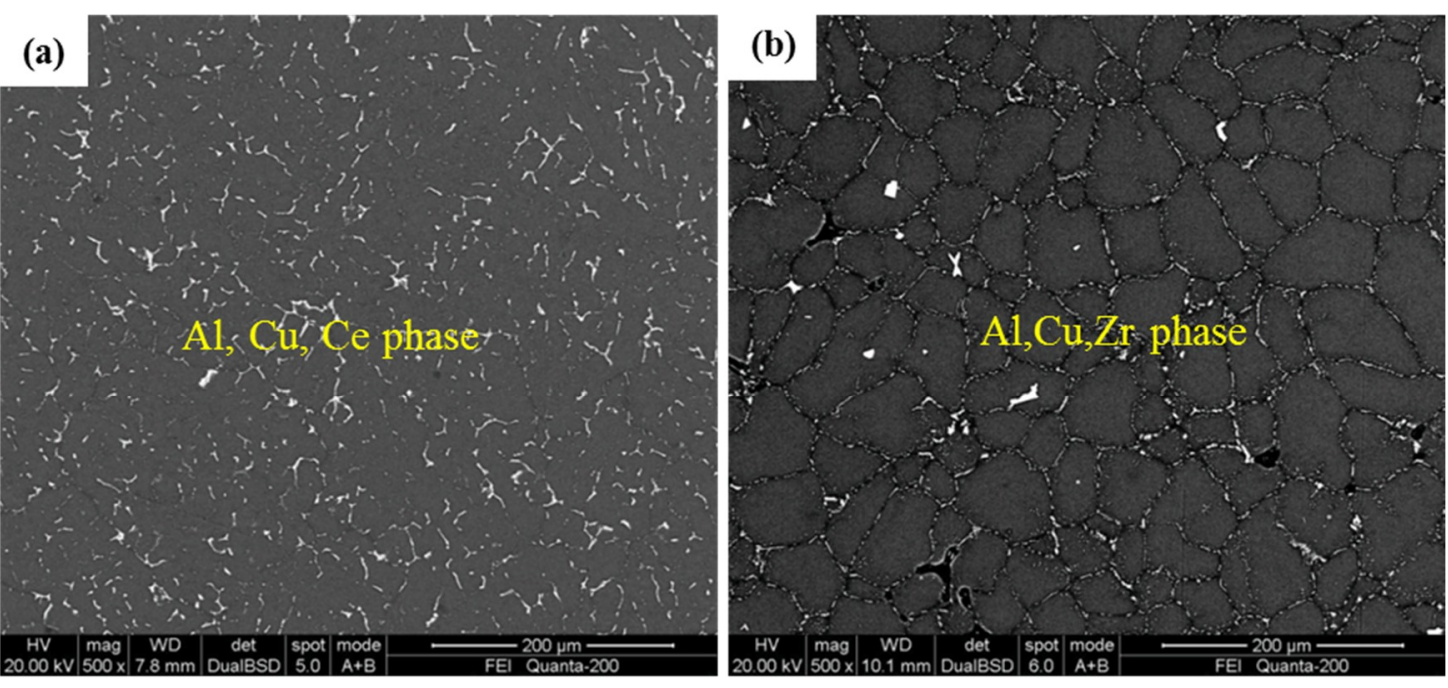

(c)

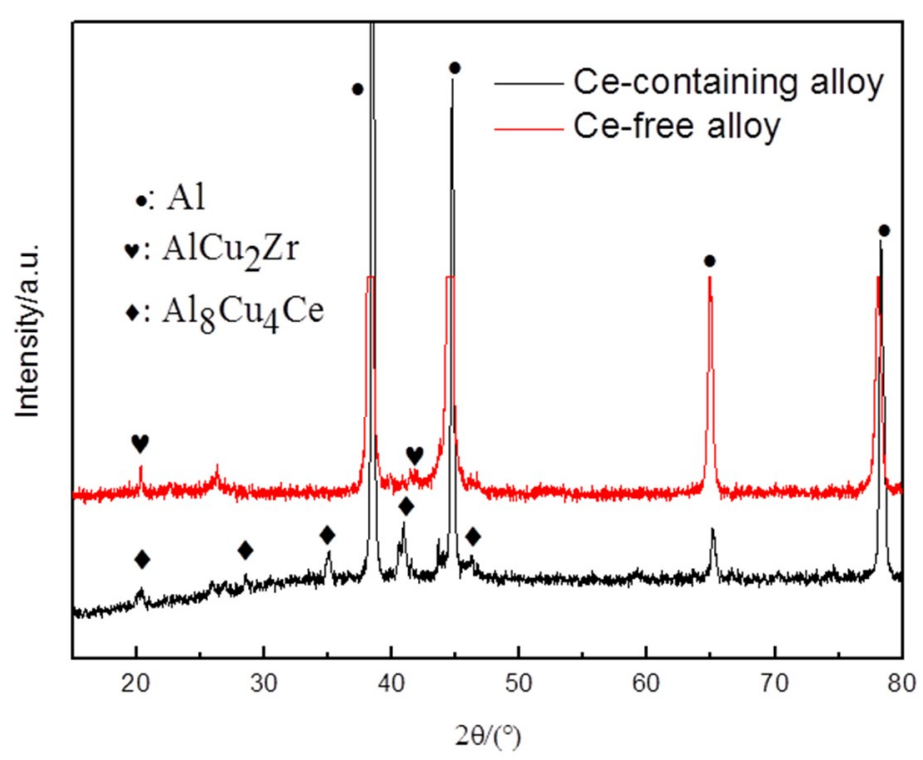

Figure 5. SEM and XRD patterns of the as-homogenized experimental alloys (a) Ce-containing alloy; (b) Ce-free alloy; (c) XRD patterns.

$\phi_{2}\left(0^{\circ}\right) \quad \phi_{2}\left(45^{\circ}\right)$

(a)

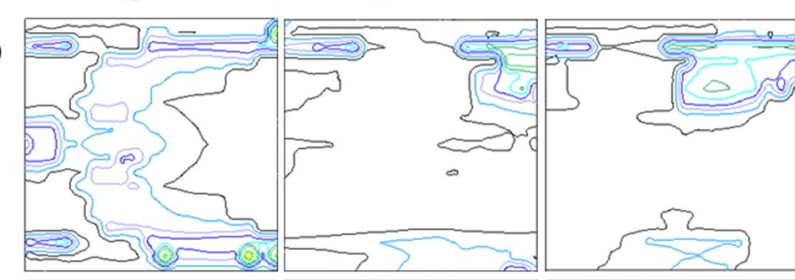

(b)

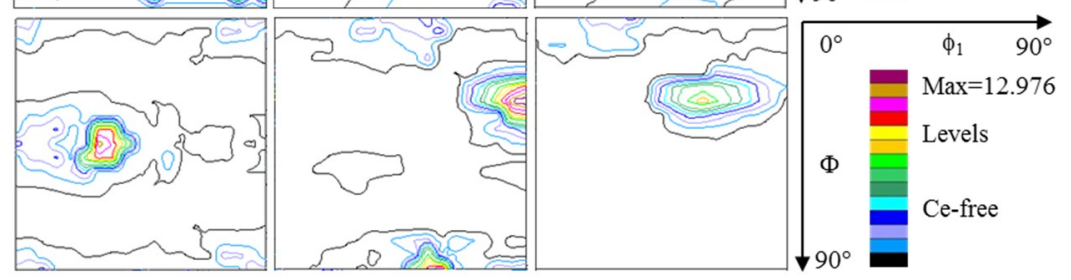

Figure 6. ODFs representative sections of the experimental alloys after the hot rolling stage. (a) Ce-containing alloy; (b) Ce-free alloy. 
Grain orientation evolution in these alloys can be clearly observed by using EBSD, as shown in Figures 7 and 8. A considerable amount of unrecrystallized deformed structures, which consisted of subgrains with a high fraction of low-angle grain boundaries, clearly remained in the Ce-containing alloy after annealing at $520^{\circ} \mathrm{C}$ for $1 \mathrm{~h}$. In contrast, a large amount of coarse equiaxial recrystallized grains with a cubic texture was observed in the Ce-free alloy. The grain orientation distributions in Figures 7 and 8 match those in Figure 1 well. Furthermore, the grain orientation evolution well explains the extent of recrystallization during the annealing process, based on transformation of the grain orientation from concentrated to more random during recrystallization. Figure 9 shows that Ce-containing alloy had a lower content of large-angle grain boundaries after annealing at 450 and $520{ }^{\circ} \mathrm{C}$ for $1 \mathrm{~h}$; this confirms a lower recrystallization degree in the Ce-containing alloy.
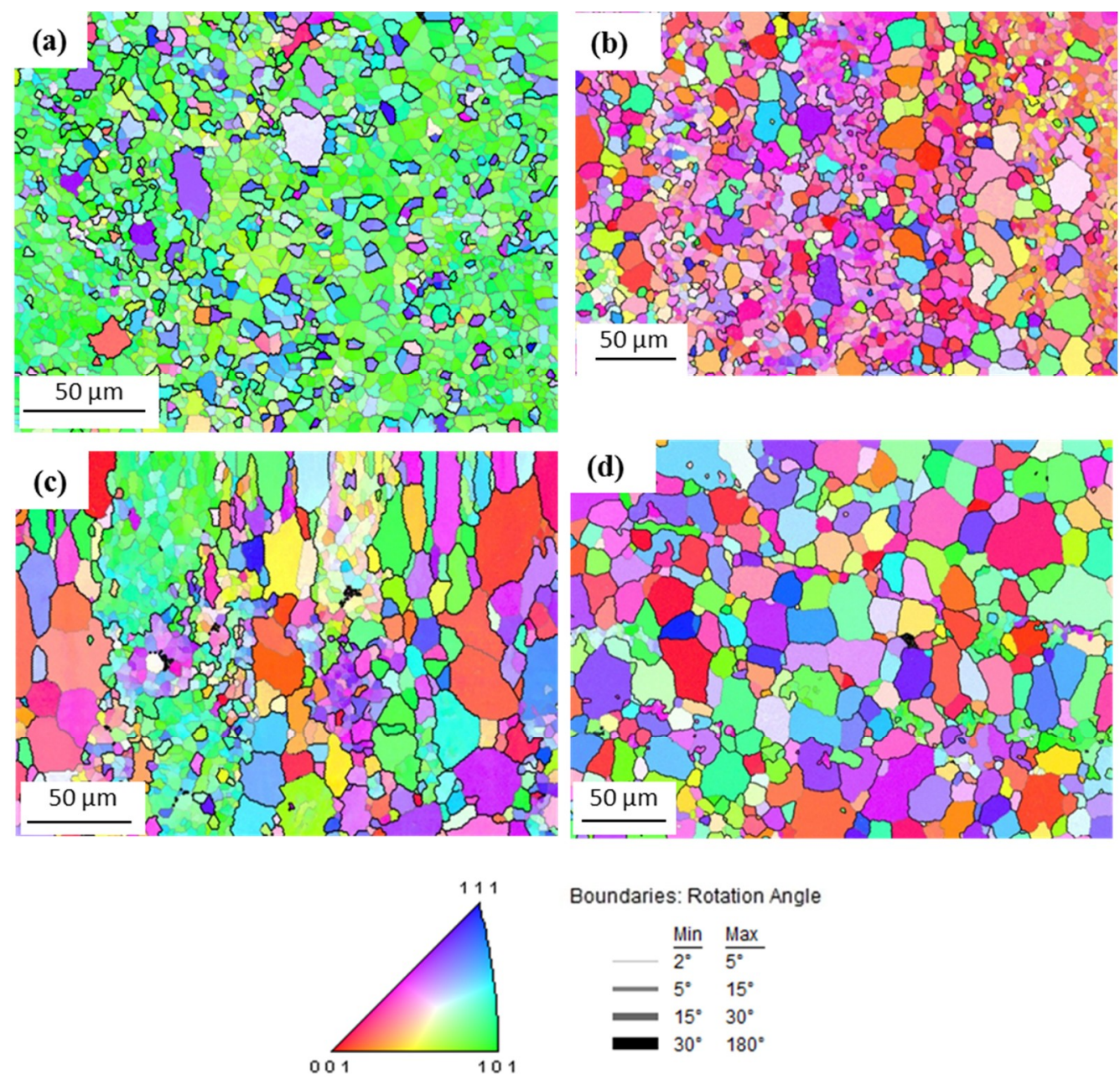

Boundaries: Rotation Angle

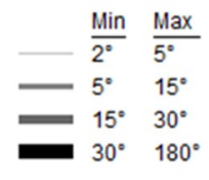

Figure 7. Micro-textures of the experimental alloys annealed under different annealing temperatures for $1 \mathrm{~h}$. Ce-containing alloy: (a) $450{ }^{\circ} \mathrm{C}$, (b) $520^{\circ} \mathrm{C}$; Ce-free alloy; (c) $450{ }^{\circ} \mathrm{C}$, (d) $520^{\circ} \mathrm{C}$. The color of each grain was coded by its crystal orientation based on [001] inverse pole figure. 
$\phi_{2}\left(0^{\circ}\right)$

(a)

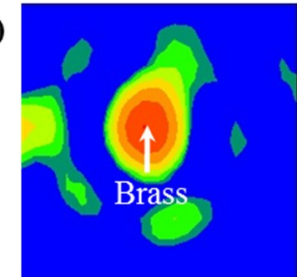

(b)

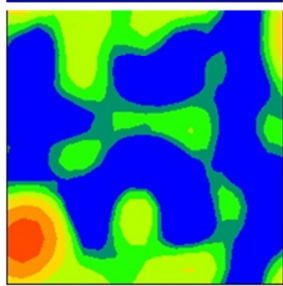

(c)

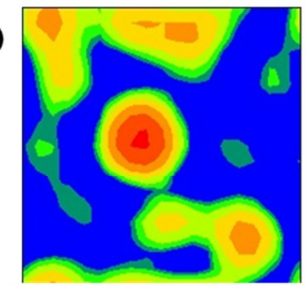

(d)

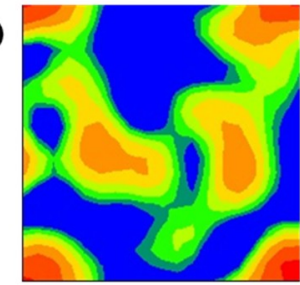

$\phi_{2}\left(45^{\circ}\right)$
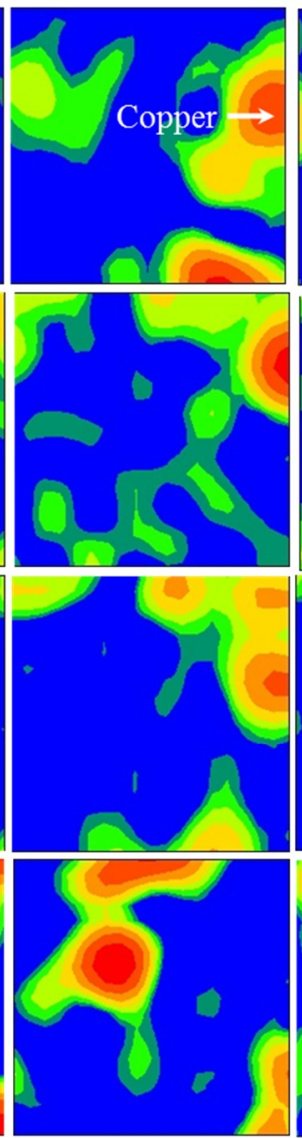

$\phi_{2}\left(65^{\circ}\right)$
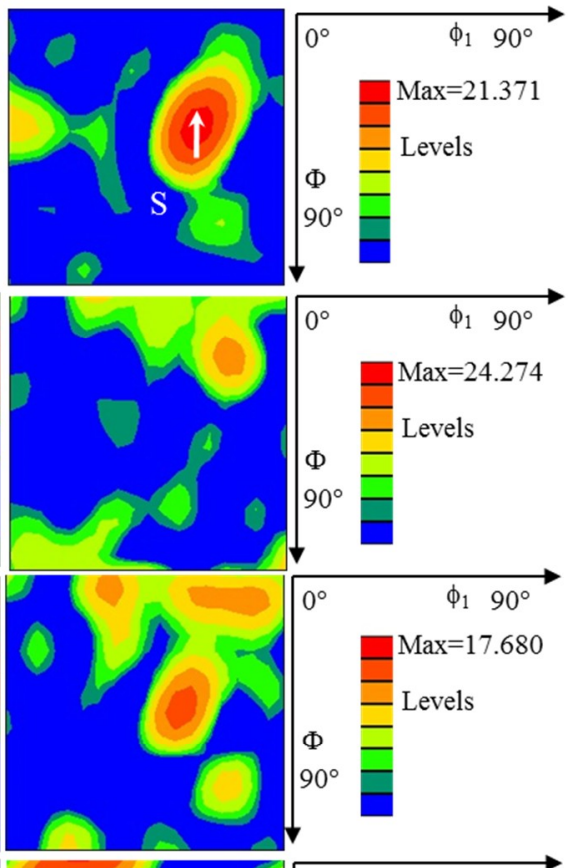

$\phi_{1} 90^{\circ}$

—Max=24.274

Levels

$\Phi$

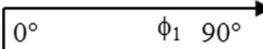

Max $=17.680$

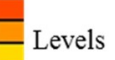

$\Phi$

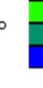

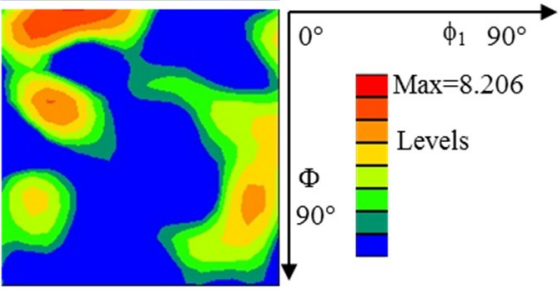

Figure 8. EBSD images of the experimental alloys annealed under different annealing temperatures for 1 h. Ce-containing alloy: (a) $450{ }^{\circ} \mathrm{C}$; (b) $520^{\circ} \mathrm{C}$; Ce-free alloy: (c) $450{ }^{\circ} \mathrm{C}$; (d) $520{ }^{\circ} \mathrm{C}$.

The form and distribution of the Ce enrichment phases were investigated by XRD and SEM to clarify the effects of $\mathrm{Ce}$ enrichment particles in $\mathrm{Al}-\mathrm{Cu}-\mathrm{Li}-\mathrm{Zr}$ alloys on inhibition of recrystallization; the results are shown in Figure 10. The SEM images and XRD patterns clearly show the presence of $\mathrm{Al}_{7} \mathrm{Cu}_{4} \mathrm{Li}$, and $\mathrm{Al}_{8} \mathrm{Cu}_{4} \mathrm{Ce}$ phases in the as-rolled Ce-containing alloy (Figure 8a,b). The improved recrystallization resistance achieved by $\mathrm{Ce}$ addition to $\mathrm{Al}-\mathrm{Cu}-\mathrm{Li}-\mathrm{Zr}$ alloy can be attributed to the formation of these finer $\mathrm{Al}_{8} \mathrm{Cu}_{4} \mathrm{Ce}$ phases. These $\mathrm{Al}_{8} \mathrm{Cu}_{4} \mathrm{Ce}$ phases had been crushed from their skeletal morphologies in the as-cast state into a smaller size by the large strain rolling [14]. $\mathrm{Al}_{8} \mathrm{Cu}_{4} \mathrm{Ce}$ phases have high-temperature stability and hardly redissolve during high-temperature annealing [15], as shown in Figure 10c. Only the fine $\mathrm{Al}_{8} \mathrm{Cu}_{4} \mathrm{Ce}$ particles with diameters smaller than $1 \mu \mathrm{m}$ have been counted, as shown in Figure 10c. The effective pinning provided by Ce-containing dispersoids is mainly restricted in the $\mathrm{Al}_{3} \mathrm{Zr}$ dispersoid-free area. As a result, only the fine $\mathrm{Al}_{8} \mathrm{Cu}_{4} \mathrm{Ce}$ particles in $\mathrm{Al}_{3} \mathrm{Zr}$ dispersoid-free area have been counted (Insider the box in Figure 10c). The estimation of the Zener pressure by fine $\mathrm{Al}_{8} \mathrm{Cu}_{4} \mathrm{Ce}$ particles has been presented, as below [29].

$$
P_{z}=\frac{3 \gamma_{G B} f_{v}}{D}
$$


(a)

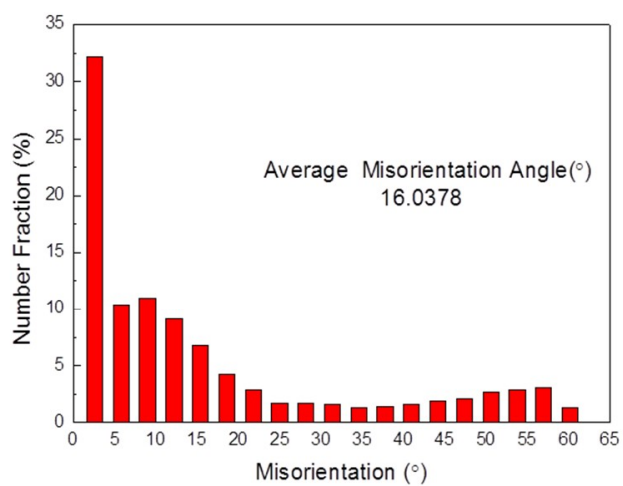

(c)

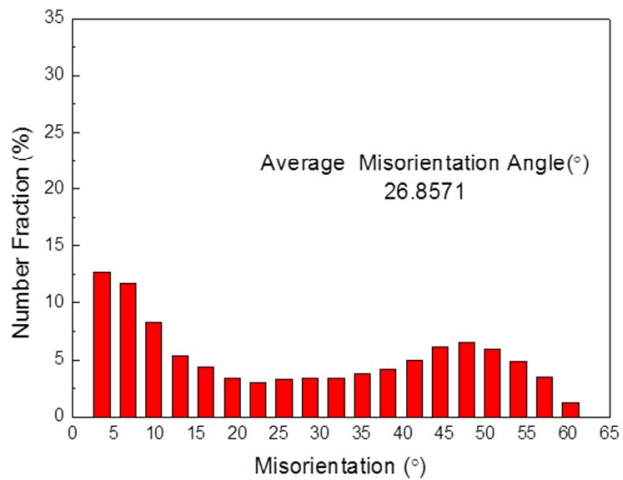

(b)

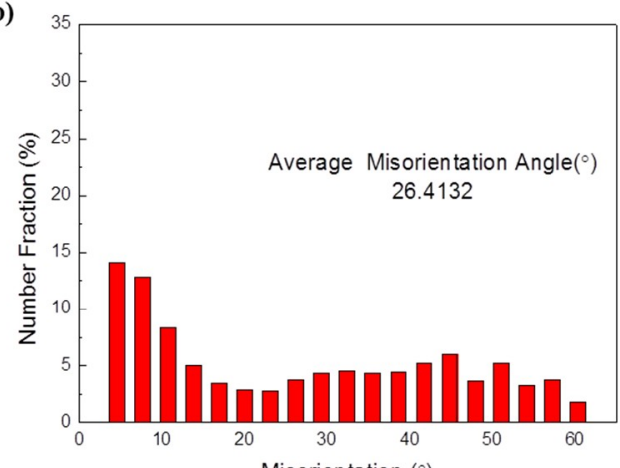

(d)

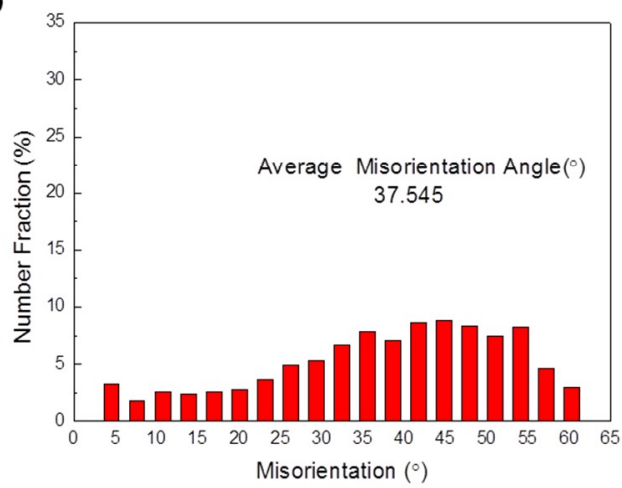

Figure 9. Grain boundary orientation angle distribution of the experimental alloys at different annealing temperatures after $1 \mathrm{~h}$ holding. Ce-containing alloy: (a) $450{ }^{\circ} \mathrm{C}$; (b) $520{ }^{\circ} \mathrm{C}$; Ce-free alloy: (c) $450{ }^{\circ} \mathrm{C}$; (d) $520{ }^{\circ} \mathrm{C}$.

For $\mathrm{Al}$ alloy the $\gamma_{G B}$ is $0.32 \mathrm{~J} / \mathrm{m}^{2}$. The size (D) and the volume fraction $\left(f_{v}\right)$ are $0.82 \mu \mathrm{m}$ and at least $6.75 \%$ respectively at present work. The estimate of the Zener pressure $P_{z}$ which is at least $79.02 \mathrm{~kJ} / \mathrm{m}^{3}$ exert on the grain boundary. So the denser distributions of these fine Ce-contining particles near grain boundary apparently cause the strong recrystallization inhibition in $\mathrm{Al}_{3} \mathrm{Zr}$ dispersoid-free grain boundary. The $\mathrm{Al}_{8} \mathrm{Cu}_{4} \mathrm{Ce}$ particles make a hole in the grain boundary (GB) and thus reduce GB area, which impose a drag force preventing the GB to escape from the particle. In order to move past the particle, a new boundary must be created, and this is energetically unfavorable [27]. These high-temperature-stable $\mathrm{Al}_{8} \mathrm{Cu}_{4} \mathrm{Ce}$ particles might exerting a Zener pressure on the boundary, especially on a dispersoid-free grain boundary, which would retard their migration [30] and inhibit recrystallization. Even the effect of Ce solute dragging on recrystallization at lower annealing temperatures can be ignored because of its extreme lower solid solubility [31]. In addition, the few ternary $\mathrm{AlCuZr}$ particles observed in the Ce-free alloy had little recrystallization-inhibiting abilities; this can be attributed to the small quantity of particles and the precipitate position. First, a certain amount of $\mathrm{Zr}$ trapped in these $\mathrm{AlCuZr}$ particles could decrease the effect of nano-sized $\mathrm{Al}_{3} \mathrm{Zr}$ particles on inhibition of recrystallization, corresponding to the higher $\mathrm{Zr}$ content in the matrix of the Ce-containing alloy $(0.32 \mathrm{wt} \%)$ than that in the Ce-free alloy $(0.13 \mathrm{wt} \%)$, as shown in Figure $8 \mathrm{~b}, \mathrm{~d}$. Secondly, few $\mathrm{AlCuZr}$ particles for recrystallization inhibition were formed near dendrite boundaries because of the low solute supersaturation in the Ce-free alloy, which contained a single dispersoid-forming element, namely Zr [11]. The enhanced inhibition of recrystallization in Ce-containing alloys can, therefore, mainly be attributed to the formation of a large number of small $\mathrm{Al}_{8} \mathrm{Cu}_{4} \mathrm{Ce}$ phases. Improved recrystallization resistance by Ce was only observed during annealing of the $\mathrm{Mg}$ alloy [17]. Similar with $\mathrm{Mn}$ and $\mathrm{Zr}$ which have the opposite microsegregation patterns in $\mathrm{Al}$ alloy [18], the joint addition of $\mathrm{Ce}$ and $\mathrm{Zr}$ in present alloy also achieves uniform dispersion coverage. In contrast to the rod-like shaped $\mathrm{Al}_{20} \mathrm{Cu}_{2} \mathrm{Mn}_{3}$ dispersoids [32], the spherical $\mathrm{Al}_{8} \mathrm{Cu}_{4} \mathrm{Ce}$ dispersoids (with much lower aspect ratio) formed in the $\mathrm{Al}_{3} \mathrm{Zr}$ dispersoid-free bands by joint addition of $\mathrm{Zr}$ and $\mathrm{Ce}$, can effectively to 
control texture, to pin grain and sub-grain migration and to inhibit recrystallization, enhancing fracture toughness at present work [13].
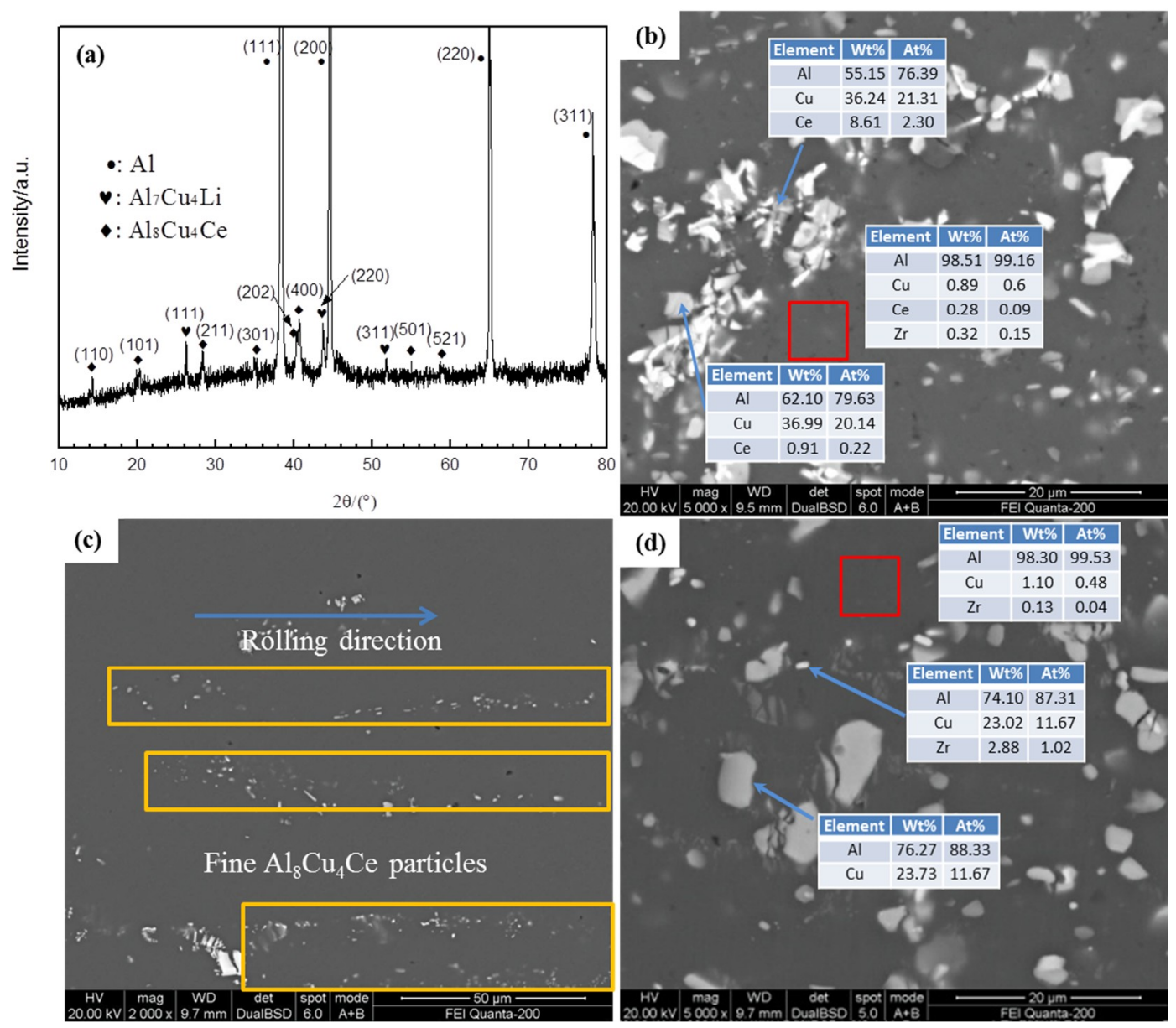

Figure 10. (a) XRD patterns of Ce-containing alloy; precipitate characterization and EDS analysis of Ce-containing alloy, (b) cold rolled and (c) after annealing at $520{ }^{\circ} \mathrm{C}$ for $1 \mathrm{~h}$; (d) Precipitate characterization and EDS analysis for cold rolled Ce-free alloy.

Figure 11 shows that the tensile strength and yield strength of the Ce-containing alloy were higher than those of the Ce-free alloy, by 21 and $38 \mathrm{MPa}$, respectively, after solid-solution and aging treatment. The average grain size (incl. sun-grain sizes) of the experimental alloy after solid solution treatment at $520^{\circ} \mathrm{C}$ for $1 \mathrm{~h}$ is $5.32 \mu \mathrm{m}$ in Ce-containing alloy and $31.23 \mu \mathrm{m}$ in Ce-free alloy respectively, as shown in Figure 7. The strength increment by grain refinement in two alloys can be achieved through Hall-Peatch relationship [33]:

$$
\Delta \sigma_{\mathrm{H}-\mathrm{P}}=k\left(d_{\mathrm{Ce}-\text { containing }}-d_{\mathrm{Ce}-\text { free }}\right)
$$

For $\mathrm{Al}$ alloy the $k$ is $0.04 \mathrm{MPa} \times \mathrm{m}^{1 / 2}$, so the strength increment in two alloys obtained by grain refinement is $10.16 \mathrm{MPa}$. However, the yield strength of the Ce-containing alloy is higher than that of the Ce-free alloy by $38 \mathrm{MPa}$ in Figure 11. The results indicate that the differences in mechanical properties are due to grain structure (26.74\%) and the final precipitation behaviour (73.26\%). Moreover, the elongations to break of the two alloys were similar. The UIE value (fracture toughness) of the Ce-containing alloy $(31.21 \mathrm{~N} / \mathrm{mm})$ was higher than that of the Ce-free alloy $(19.97 \mathrm{~N} / \mathrm{mm})$. The grain size is one of the main factors that affect the fracture toughness and ductility of a material, therefore, the grain properties of these two alloys after solid-solution and aging treatment are shown in the three-dimensional optical micrographs in Figure 10. There are clearly many more small grains and 
fiber-like unrecrystallized microstructures distributed along the rolling direction in the Ce-containing alloy after solid-solution and aging treatment (Figure 12a). There are many coarse recrystallized grains distributed in the Ce-free alloy (Figure 12b). The critical effective shear stress and energy of plastic deformation, which are affected by the grain size, are key factors in crack initiation and propagation during deformation of alloys $[4,30]$. These properties determine the overall performance (strength, fracture toughness, etc.) of an alloy. The critical effective shear stress at fracture or crack nucleation should be considered first because gliding dislocations can accumulate at grain boundaries during continuous deformation and some cracks may be formed by piled-up dislocations. The crack initiation resistance is improved by grain refinement in the Ce-containing alloy because the critical effective shear stress at fracture increases with decreasing grain diameter [30]. Moreover, the fiber-like unrecrystallized microstructures or smaller grain size in the Ce-containing alloy result in larger grain boundary areas. The crack propagation paths are more tortuous, which results in higher crack propagation resistance and higher energy of plastic deformation [4]. This analysis is consistent with the higher strength and fracture toughness, and uniform elongation results for the Ce-containing alloy in Figure 11.

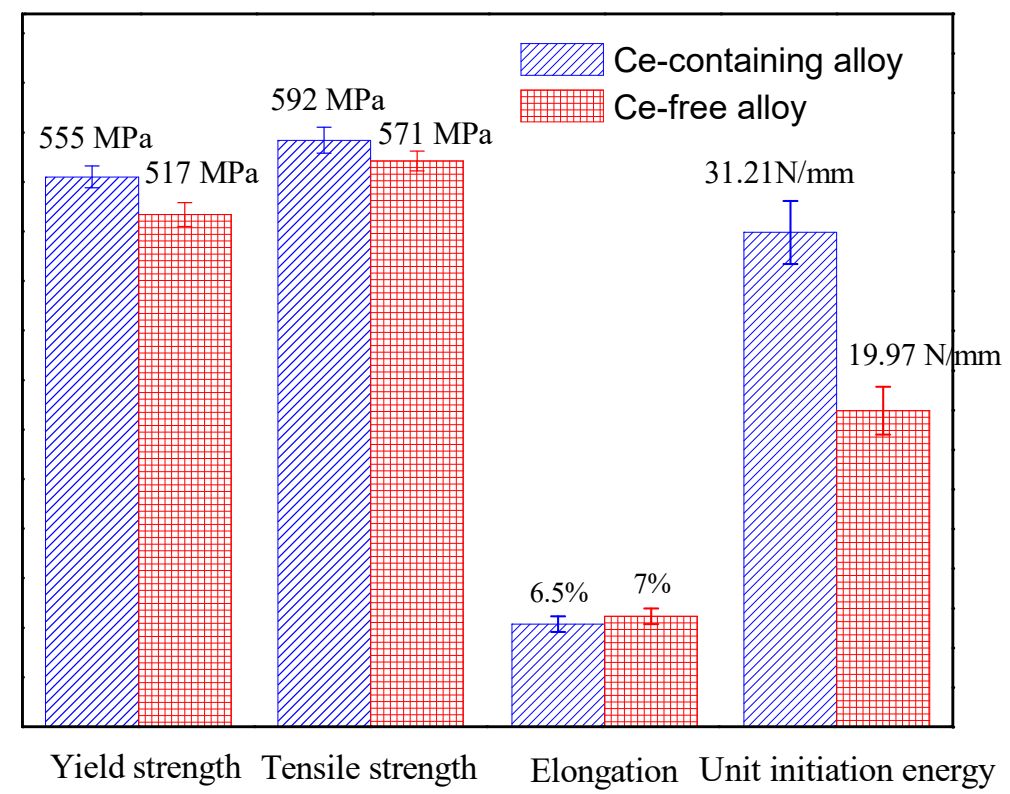

Figure 11. Tensile properties and fracture toughness of the experimental alloys after solution and aging treatment $\left(520^{\circ} \mathrm{C} / 1 \mathrm{~h}\right.$ and $\left.180^{\circ} \mathrm{C} / 22 \mathrm{~h}\right)$.

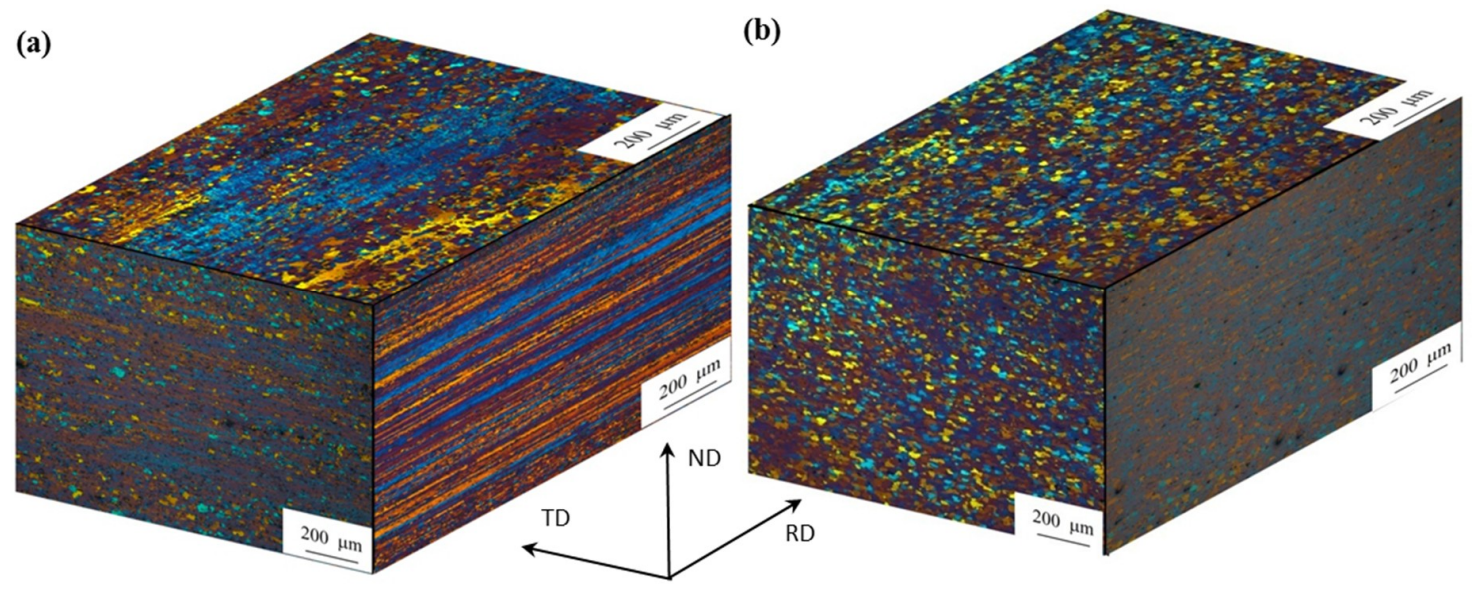

Figure 12. Three direction optical micrographs of (a) Ce-containing and (b) Ce-free alloys after annealing at $520^{\circ} \mathrm{C}$ for $1 \mathrm{~h}$. 


\section{Conclusions}

Inhibition of recrystallization in an $\mathrm{Al}-\mathrm{Cu}-\mathrm{Li}-\mathrm{Zr}$ alloy through $\mathrm{Ce}$ addition during isothermal annealing after high-strain rolling was investigated. Improved recrystallization resistance was confirmed by optical microscopy, and observation of texture and microstructures during isothermal annealing. Considerable enhancement of the fracture toughness and tensile strength were achieved by inhibiting recrystallization. The following conclusions can be drawn.

(1) The recrystallization degree of an Al-Cu-Li-0.13Zr-0.29Ce alloy is far lower than that of an $\mathrm{Al}-\mathrm{Cu}-\mathrm{Li}-0.14 \mathrm{Zr}$ alloy under the same conditions, for all annealing processes. This reflects the deformation/recrystallization texture transitions at higher annealing temperatures and longer annealing times in the $\mathrm{Al}-\mathrm{Cu}-\mathrm{Li}-0.13 \mathrm{Zr}-0.29 \mathrm{Ce}$ alloy, in which much larger amounts of $\beta$-fibers and fibrous unrecrystallized grain microstructures were distributed along the rolling direction in the overall annealing process.

(2) The enhanced recrystallization resistance of the $\mathrm{Al}-\mathrm{Cu}-\mathrm{Li}-0.13 \mathrm{Zr}-0.29 \mathrm{Ce}$ alloy can be attributed to the formation of a large number of small $\mathrm{Al}_{8} \mathrm{Cu}_{4} \mathrm{Ce}$ phases on dispersoid-free grain boundaries. These high-temperature-stable particles might produce Zener pinning pressure on $\mathrm{Zr}$ dispersoid-free grain boundaries, and retarded its migration.

(3) The Al-Cu-Li-0.13Zr-0.29Ce alloy had high tensile and yield strengths, i.e., 592 and $555 \mathrm{MPa}$, respectively. The UIE value (fracture toughness) of this alloy $(31.21 \mathrm{~N} / \mathrm{mm}$ ), was higher than that of the $\mathrm{Al}-\mathrm{Cu}-\mathrm{Li}-0.14 \mathrm{Zr}$ alloy $(19.97 \mathrm{~N} / \mathrm{mm})$. This is because of its finer grain size.

Author Contributions: Conceptualization, X.Y.; Data curation, J.S. and C.L.; Investigation, J.Z.; Methodology, H.D.; Project administration, X.Y. and H.D.; Resources, Z.L. and W.L.; Supervision, X.Y.; Validation, X.Y.; Writing - original draft, X.Y.

Funding: This research was funded by (Natural Science Foundation of Shandong Province, China) grant number (ZR2017PEM005); (A Project of Shandong Province Higher Educational Science and Technology Program) grant number (No. J17KA043, J17KB076 and J18KA053).

Acknowledgments: We thank Helen McPherson, from Liwen Bianji, Edanz Editing China (www.liwenbianji.cn/ ac), for editing the English text of a draft of this manuscript. We also thank Xiaoyan Dong, from Yantai Nanshan University, for editing the English text of a revised manuscript.

Conflicts of Interest: The authors declare no conflict of interest.

\section{References}

1. Rodgers, B.I.; Prangnell, P.B. Quantification of the influence of increased pre-stretching on microstructure-strength relationships in the Al-Cu-Li alloy AA2195. Acta Mater. 2016, 108, 55-67. [CrossRef]

2. Fang, H.C.; Chen, K.H.; Zhang, Z.; Zhun, C.J. Effect of $\mathrm{Yb}$ additions on microstructures and properties of 7A60 aluminum alloy. Trans. Nonferrous Met. Soc. China 2008, 18, 28-32. [CrossRef]

3. Fang, H.C.; Chao, H.; Chen, K.H. Effect of recrystallization on intergranular fracture and corrosion of Al-Zn-Mg-Cu-Zr alloy. J. Alloys Compd. 2015, 622, 166-173. [CrossRef]

4. Qin, C.; Gou, G.Q.; Che, X.L.; Chen, H.; Chen, J.; Li, P.; Gao, W. Effect of composition on tensile properties and fracture toughness of Al-Zn-Mg alloy (A7N01S-T5) used in high speed trains. Mater. Des. 2016, 91, 278-285. [CrossRef]

5. Cong, F.G.; Zhao, G.; Jiang, F.; Tian, N.; Li, R.F. Effect of homogenization treatment on microstructure and mechanical properties of DC cast $7 \times 50$ aluminum alloy. Trans. Nonferrous Met. Soc. China 2015, 25, 1027-1034. [CrossRef]

6. Pasang, T.; Symonds, N.; Moutsos, S.; Wanhill, R.J.H.; Lynch, S.P. Low-energy intergranular fracture in Al-Li alloys. Eng. Fail. Anal. 2012, 22, 166-178. [CrossRef]

7. Ma, J.; Yan, D.S.; Rong, L.J.; Li, Y.Y. Effect of Sc addition on microstructure and mechanical properties of 1460 alloy. Prog. Nat. Sci. 2014, 24, 13-18. [CrossRef]

8. Luca, A.D.; Dunand, D.C.; Seidman, D.N. Mechanical properties and optimization of the aging of a dilute Al-Sc-Er-Zr-Si alloy with a high Zr/Sc ratio. Acta Mater. 2016, 119, 35-42. [CrossRef]

9. Li, H.Y.; Gao, Z.H.; Yin, H.; Jiang, H.F.; Su, X.J.; Bin, J. Effects of Er and Zr additions on precipitation and recrystallization of pure aluminum. Scr. Mater. 2013, 68, 59-62. [CrossRef] 
10. Guo, Z.Y.; Zhao, G.; Chen, X.G. Effects of two-step homogenization on precipitation behavior of $\mathrm{Al}_{3} \mathrm{Zr}$ dispersoids and recrystallization resistance in 7150 aluminum alloy. Mater. Charact. 2015, 102, $122-130$. [CrossRef]

11. Tsivoulas, D.; Robson, J.D.; Sigli, C.; Prangnell, P.B. Interactions between zirconium and manganese dispersoid-forming elements on their combined addition in Al-Cu-Li alloys. Acta Mater. 2012, 60, 5245-5259. [CrossRef]

12. Wu, H.; Wen, S.P.; Huang, H.; Li, B.L.; Wu, X.L.; Gao, K.Y.; Wang, W.; Nie, Z.R. Effects of homogenization on precipitation of $\mathrm{Al}_{3}(\mathrm{Er}, \mathrm{Zr})$ particles and recrystallization behavior in a new type $\mathrm{Al}-\mathrm{Zn}-\mathrm{Mg}-\mathrm{Er}-\mathrm{Zr}$ Alloy. Mater. Sci. Eng. A 2017, 689, 313-322. [CrossRef]

13. Balducci, E.; Ceschini, L.; Messieri, S.; Wenner, S.; Holmestad, R. Thermal stability of the lightweight 2099 Al-Cu-Li alloy: Tensile tests and microstructural investigations after overaging. Mater. Des. 2017, 119, 54-64. [CrossRef]

14. Yu, X.X.; Yin, D.F.; Yu, Z.M.; Zhang, Y.R.; Li, S.F. Solidification behaviour and the effects of cerium on the intermetallic structure of a novel Al-Cu-Li alloy. Rare Met. Mater. Eng. 2016, 45, 1423-1429. [CrossRef]

15. Yu, X.X.; Yin, D.F.; Yu, Z.M.; Zhang, Y.R.; Li, S.F. Microstructure evolution of a novel Al-Cu-Li-Ce alloy during homogenization. Rare Met. Mater. Eng. 2016, 45, 1687-1694. [CrossRef]

16. Bo, H.; Jin, S.; Zhang, L.G.; Chen, X.M.; Chen, H.M.; Liu, L.B.; Zheng, F.; Jin, Z.P. Thermodynamic assessment of Al-Ce-Cu system. J. Alloys Compd. 2009, 484, 286-295. [CrossRef]

17. Basu, I.; Al-Samman, T. Triggering rare earth texture modification in magnesium alloys by addition of zinc and zirconium. Acta Mater. 2014, 67, 116-133. [CrossRef]

18. Tsivoulas, D.; Robson, J.D. Heterogeneous $\mathrm{Zr}$ solute segregation and $\mathrm{Al}_{3} \mathrm{Zr}$ dispersoid distributions in Al-Cu-Li alloys. Acta Mater. 2015, 93, 73-86. [CrossRef]

19. Xiao, D.H.; Wang, J.N.; Ding, D.Y.; Yang, H.L. E ffect of rare earth Ce addition on the microstructure and mechanical properties of an Al-Cu-Mg-Ag alloy. J. Alloys Compd. 2003, 352, 84-88. [CrossRef]

20. Chaubey, A.K.; Mohapatra, S.; Jayasankar, K.; Pradhan, S.K.; Satpati, B.; Sahay, S.S.; Mishra, B.K.; Mukherjee, P.S. Effect of cerium addition on microstructure and mechanical properties of Al-Zn-Mg-Cu alloy. Trans. Indian Inst. Met. 2009, 62, 539-543. [CrossRef]

21. Lai, J.P.; Jiang, R.P.; Liu, H.S.; Dun, X.L.; Li, Y.F.; Li, X.Q. Influence of cerium on microstructures and mechanical properties of Al-Zn-Mg-Cu alloys. J. Cent. South Univ. Technol. 2012, 19, 869-874. [CrossRef]

22. Zhu, K.Y.; Chaubet, D.; Bacroix, B.; Brisset, F. A study of recovery and primary recrystallization mechanisms in a Zr-2Hf alloy. Acta Mater. 2005, 53, 5131-5140. [CrossRef]

23. Yu, X.X.; Zhang, Y.R.; Yin, D.F.; Yu, Z.M.; Li, S.F. Characterization of Hot Deformation Behavior of a Novel Al-Cu-Li Alloy Using Processing Maps. Acta Metall. Sin. 2015, 28, 817-825. [CrossRef]

24. Dumont, D.; Deschamps, A.; Brechet, Y. On the relationship between microstructure, strength and toughness in AA7050 aluminum alloy. Mater. Sci. Eng. A 2003, 356, 326-336. [CrossRef]

25. Samman, T.A. Modification of texture and microstructure of magnesium alloy extrusions by particlestimulated recrystallization. Mater. Sci. Eng. A 2013, 560, 561-566. [CrossRef]

26. Robson, J.D.; Henry, D.T.; Davis, B. Particle effects on recrystallization in magnesium-manganese alloys: Particle-stimulated nucleation. Acta Mater. 2009, 57, 2739-2747. [CrossRef]

27. Humphreys, F.J.; Hatherly, M. Recrystallization of two-phase alloys. In Recrystallization and the Related Annealing Phenomena, 2nd ed.; Sleeman, D., Ed.; Elsevier: Oxford, UK, 2004; pp. 293-302.

28. Deng, Y.; Xu, G.; Yin, Z.; Lei, X.; Huang, J. Effects of Sc and Zr microalloying additions on the recrystallization texture and mechanism of Al-Zn-Mg alloys. J. Alloys Compd. 2013, 580, 412-426. [CrossRef]

29. Vatne, H.E.; Furu, T.; Ørsund, R.; Nes, E. Modelling recrystallization after hot deformation of aluminium. Acta Mater. 1996, 44, 4463-4473. [CrossRef]

30. Zuo, J.R.; Hou, L.G.; Shi, J.T.; Cui, H.; Zhuang, L.Z.; Zhang, J.S. The mechanism of grain refinement and plasticity enhancement by an improved thermomechanical treatment of $7055 \mathrm{Al}$ alloy. Mater. Sci. Eng. A 2017, 702, 42-52. [CrossRef]

31. Robson, J.D. Effect of Rare-Earth Additions on the Texture of Wrought Magnesium Alloys. Metall. Mater. Trans. A 2014, 45, 3205-3212. [CrossRef] 
32. Tsivoulas, D.; Prangnell, P.B. The effect of $\mathrm{Mn}$ and $\mathrm{Zr}$ dispersoid-forming additions on recrystallization resistance in Al-Cu-Li AA2198 sheet. Acta Mater. 2014, 77, 1-16. [CrossRef]

33. Hansen, N. Hall-Petch relation and boundary strengthening. Scr. Mater. 2004, 51, 801-806. [CrossRef]

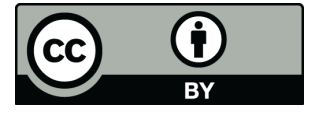

(C) 2018 by the authors. Licensee MDPI, Basel, Switzerland. This article is an open access article distributed under the terms and conditions of the Creative Commons Attribution (CC BY) license (http://creativecommons.org/licenses/by/4.0/). 